\title{
China Mediation Diplomacy in the Middle East Conflicts
}

\author{
Mordechai Chaziza* \\ Department of Politics and Governance, Bar-Ilan University, Israel
}

Submission: June 17, 2018; Published: July 05, 2018

*Corresponding author: Mordechai Chaziza, Bar-Ilan University and Senior Lecturer in Department of Politics and Governance, Ashkelon Academic College Ben Zvi12 Ashkelon, Israel. Specializing in Chinese foreign and strategic relations, Israel, Tel: (972) 50 6874452; Email: motih1308@gmail.com

\section{Opinion}

Mediation diplomacy has emerged as one of the central pillars of China's foreign policy objectives and practice, with Beijing deliberately positioning itself as a peacemaker in the Middle East conflicts and crises in the region (e.g. Afghanistan, Syria, Sudan, Yemen, Iran, and the Israeli-Palestinian peace process). Over the decades, many global and regional players have intervened at some degree in the Middle East conflicts as peace brokers. The US, the EU., Russia, and regional powers (e.g., Egypt, Turkey and Saudi Arabia) and major international organizations have all tried -without noticeable success - to broker a lasting peace and security in the region. China, unlike the other players, carries no religious, political, historical, and colonial baggage, making it an ideal candidate to break the gridlocks in the region's conflicts and to play the role of an 'honest broker'.

In the Middle East, the U.S, and other players are perceived to have manifold agendas and interests across the area. Therefore, the mediation process are frequently seen as a means of furthering their own specific interests and goals. China's, traditionally, stance toward the Middle East, as all other regions of the world, has been based on the principles of sovereignty and non-intervention in internal affairs. However, there has always been a degree of flexibility and pragmatism in how Beijing conducts its foreign policy, especially when it comes to nonintervention practice. Specifically, China does not involve itself in the internal affairs of other countries, unless its own national or economic interests are in danger or at risk.

In recent years, China has gradually integrated itself into and expanded within the Middle East, and its foreign policy has become subtler and more sophisticated, with a growing inconsistencybetween its principles and practice. Its more flexible and pragmatic interpretive approach and implementation of the principle of non-intervention, are driven by Beijing's growing need for imports of energy and raw materials in order to maintain domestic economic growth and stability, which continues to be the top priority for the legitimacy of the Chinese regime. The unstable political situation in the Middle East caused Beijing to become more deeply and more proactively involved, to protect its own interests, with the result that the Middle East countries increasingly expect that China will become a stabilizing actor in the political and security regional affairs,and play an active role in the conflict settlement efforts.

Nevertheless, despite growing expectations of China in this area, Beijing is not yet ready to take on such responsibilities. Instead, China's efforts focused mainly on conflict management such as, calling for a reduction of tension or conducting a dialogue between the parties and offers to play a mediating role in part of the conflicts and crises in the region (e.g. Afghanistan, Syria, Sudan, and Iran) to protect its own, mainly economic stakes. Moreover, China seeks to manage the disputes in the Middle East by strengthening bilateral and multilateral cooperation with other great powers and regional organizations (e.g., Iranian nuclear crisis and Syria civil war). Thus, while adhering to its fundamental and uncompromising principle of non-intervention, China's flexible approach has created certain criteria for developing a role as conflict manager and peace broker. Since China mediation diplomacy is initiated and performed only on a voluntary basis, and its recommendations are non-binding, its mediator role is the 'legitimate way' to intervene or to influence the domestic politics of other states, and to protect its national economic, as well as to promote its political interests in the region.

More importantly, Beijing's mediation diplomacy in the Middle East conflicts should be perceived through the prism of 'Chinese characteristics' of conflict management. Beijing's willingness to play the role of mediator in conflict perfectly suits its non-intervention policy framework, which is limited to participating in multilateral peace mediation and projecting a positive image of a reliable regional power or key stakeholder. Chinese mediation diplomacy always aim to include and mobilize all local forces or groups concerned while outside forces can only play a supporting role. 
(C) This work is licensed under Creative CC (1) Commons Attribution 4.0 License BY DOI: 10.19080/RAPSCI.2018.05.555665
Your next submission with Juniper Publishers will reach you the below assets

- Quality Editorial service

- Swift Peer Review

- Reprints availability

- E-prints Service

- Manuscript Podcast for convenient understanding

- Global attainment for your research

- Manuscript accessibility in different formats

( Pdf, E-pub, Full Text, Audio)

- Unceasing customer service

Track the below URL for one-step submission https://juniperpublishers.com/online-submission.php 